\title{
Disease-Associated Systemic Complications in Childhood Nephrotic Syndrome: A Systematic Review
}

\author{
Dany Hilmanto $\mathbb{D}^{\prime}$, Fitriana Mawardi $\mathbb{D}^{2}$, Ayuningtyas S Lestari ${ }^{3}$, Ahmedz Widiasta $\mathbb{D}^{\prime}$ \\ 'Division of Nephrology, Department of Child Health, Faculty of Medicine, Universitas Padjadjaran, Bandung, West Java, Indonesia; ${ }^{2}$ Community and \\ Family Medicine Department, Faculty of Medicine, Public Health and Nursing, Universitas Gadjah Mada, Yogyakarta, Yogyakarta, Indonesia; ${ }^{3}$ Nursing \\ Department, Faculty of Medicine, Public Health and Nursing, Universitas Gadjah Mada, Yogyakarta, Yogyakarta, Indonesia
}

Correspondence: Dany Hilmanto, Division of Nephrology, Department of Child Health, Faculty of Medicine, Universitas Padjadjaran, 38 Jalan Professor Eyckman, Pasteur, Sukajadi, Bandung, West Java, Indonesia, Email danyhilmanto@yahoo.com

\begin{abstract}
Introduction: Nephrotic syndrome (NS) is one of the most common childhood kidney diseases. During the active phase, the disease pathogenesis affects various biological functions linked to loss of proteins negatively, which can result in systemic complications. Complications of childhood NS are divided into two categories: disease-associated complications and drug-associated complications. However, complications in pediatric patients with NS, especially disease-associated complications are still limited. Although reported in the literature, information is not comprehensive and needs to be updated. This study aimed to systematically assess systemic complications in children with NS, especially disease-associated complications, to better understand how they impact outcomes.

Methods: We conducted a systematic search of several databases: BioMed Central Pediatrics, PubMed, Google Scholar, the National Library of Medicine, Cochrane Library, CINAHL/EBSCO, British Medical Journal, Science Direct, Scopus, and Elsevier's ClinicalKey. We followed the PRISMA guidelines to plan, conduct, and report this review. We used the Joanna Briggs Institute's critical appraisal tools for assuring the quality of the journal articles that were chosen.

Results: Eleven articles concerning complications in childhood NS were analyzed. Systemic disease-associated complications in covered were cardiovascular complications, infections, thyroid-hormone complication, kidney complications, and oral health complications.

Conclusion: NS is marked by heavy proteinuria, hypoalbuminemia, edema, and hyperlipidemia, which can result in systemic diseaseassociated complications. Cardiovascular complications, infections, thyroid-hormone complications, kidney complications, and oral health complications are the main systemic complications in childhood NS. It is essential that health-care providers prevent these complications for proper maintenance of patients' health.
\end{abstract}

Keywords: disease complications, nephrotic syndrome, pediatric, systemic complications

\section{Introduction}

One of the most common childhood kidney diseases is nephrotic syndrome (NS). ${ }^{1}$ The prevalence of childhood NS worldwide is approximately 16 cases per 100,000 children, with an incidence of two to seven per 100,000 children. Primary causes of NS include minimal change disease, focal segmental glomerulosclerosis, membranous nephropathy, genetic disorders, and secondary diseases associated with infections, drugs, and neoplasia; however, it can also be idiopathic. NS can affect children of any age from infancy to adolescence and predominantly occurs in those aged 1-6 years. $^{2}$

Four specific symptoms of NS are heavy proteinuria, hypoalbuminemia, edema, and hyperlipidemia. ${ }^{3}$ Patients with NS may have nephritic characteristics, such as hypertension, hematuria, and decreased kidney function. Similarly, patients with a nephritic disease may have nephrotic features. ${ }^{4}$ NS may have common physical changes and injury in the glomerular filtration barrier, resulting in a massive leak of serum proteins into the urine causing proteinuria. ${ }^{1}$ 
NS has become one of the most common primary kidney diseases, and progressive forms can result in chronic kidney disease. Most patients with NS have a good response to steroid therapy and consequently a good prognosis. The treatment recommendation from the International Study of Kidney Disease in Children (ISKDC) is steroids, and initial remission $>9$ days and first relapse within 6 months are associated with frequent relapses. ${ }^{1,5}$ Based on the prospective and multicenter study conducted by ISKDC, a vast majority of patients with minimal change NS had responded to steroid therapy by 4 weeks. ${ }^{6,7}$ However, approximately $10 \%$ of children suffer steroid resistance and show no response to steroid therapy and have a poor prognosis. ${ }^{8}$

The loss of proteins negatively affects various biological functions during active disease, which can result in complications. ${ }^{4}$ Complications of childhood NS are divided into two categories: disease-associated complications and drug-associated complications. ${ }^{9}$ Drug-associated complications include sensitivity to steroids, which are used for the treatment of NS. Steroid treatment is associated with severe side effects, such as growth retardation, hypertension, osteoporosis, and bone fractures, and is also linked with psychological stress. ${ }^{10}$ Treatment duration also affects psychosocial and developmental phase in the form of internal problems, somatic complaints, and anxiety/ depression, which can decrease the quality of life. ${ }^{11}$

However, complications - especially disease-associated ones — in pediatric patients with NS are still limited. Although reported in the literature, information is not comprehensive and needs to be updated. Parents and caregivers are often worried about the long-term health outcomes for their children with NS, due to a lack of knowledge about these complications. ${ }^{12}$ Most of the data related to complications in childhood NS are based on case reports, and there is a scarcity of systematic reviews. The aim of the study was to systematically assess disease-associated complications in children with NS to better understand how they impact outcomes. By understanding these complications, among healthcare providers will be able to better manage children with NS to prevent the complications and aid decision-making on proper treatment programs.

\section{Methods}

We conducted a systematic review to analyze NS complications in children from Asia, Europe, the US, and Africa (Table 1). We followed the PRISMA guidelines for planning, conducting, and reporting.

\section{Eligibility Criteria}

Eligibility for inclusion was original research in English containing primary data on disease-associated complications in children with NS aged 0-18 years published in the last 5 years. We excluded case reports and reviews, where the study population comprised both children and adults, diagnosis was not NS, or only systemic diseases associated with NS were reported.

\section{Search Strategy}

We searched BioMed Central Pediatric, PubMed, Google Scholar, the National Library of Medicine, Cochrane Library, British Medical Journal, Science Direct, Scopus, and Elsevier's ClinicalKey. Initially, we identified all potentially relevant articles without date restrictions. Next, we restricted the search to include only publications in the last five years (2016-2021). Search terms used wered "NS" AND "pediatric" OR "child" OR "children" OR "childhood" AND "complication" OR "complications." Sources cited in any review articles were cross-referenced for additional relevant articles. Two reviewers (FM and ASL) screened the titles based on relevance, followed by selection of abstracts from potentially relevant titles based on the eligibility criteria. Lastly, we analyzed the full-text articles. Mendeley software was used to manage references, and any duplicates were removed.

\section{Data Extraction}

We used data-extraction forms to assess each population, setting, and focus. The aim, study design, subject, and main results were used for data extraction. Data were extracted by two reviewers (FM and ASL) and checked by two other reviewers (DH and AW). The main finding were assessed for relevance related to complications in childhood NS. We then compared the main findings to identify and address the objectives of this review. 


\begin{tabular}{|c|c|c|c|c|c|}
\hline Study & Country & Aim & Sample & Methods & Findings \\
\hline Youssef et $\mathrm{al}^{\beta 3}$ & Egypt & $\begin{array}{l}\text { To investigate the correlation between carotid } \\
\text { intima-media thickness (CIMT) and brachial } \\
\text { artery flow-mediated dilatation with } \\
\text { cardiovascular risk factors in patients with } \\
\text { nephrotic syndrome }\end{array}$ & $\begin{array}{l}\text { Patients }(n=31) \text { with nephrotic } \\
\text { syndrome aged 3-10 years }\end{array}$ & $\begin{array}{l}\text { - Case-control observational study to } \\
\text { compare patients with nephrotic syndrome } \\
\text { and controls. } \\
\text { - All children were subjected to full history } \\
\text { taking thorough clinical examination and } \\
\text { laboratory investigations in the form of fasting } \\
\text { lipid profile, serum urea and creatinine, total } \\
\text { protein and serum albumin, CRP, ferritin, and } \\
\text { urine protein:creatinine ratio. } \\
\text { - All children were also subjected to imaging } \\
\text { techniques. }\end{array}$ & $\begin{array}{l}\text { - Serum cholesterol, low-density lipoprotein cholesterol, } \\
\text { and triglyceride levels were significantly higher in the case } \\
\text { group than the control group. } \\
\text { - High-density lipoprotein cholesterol and albumin levels } \\
\text { were significantly lower in the case group. } \\
\text { - Absolute change in brachial artery diameter was } \\
\text { significantly lower in the case group. } \\
\text { - Proportional change in brachial artery diameter was } \\
\text { significantly lower in the case group. } \\
\text { - CIMT in the case group was significantly higher. } \\
\text { - Patients with NS were more prone to atherosclerosis and } \\
\text { vascular changes. }\end{array}$ \\
\hline Ali et $a^{34}$ & Iraq & $\begin{array}{l}\text { To study serum lipids, PONI, and LCAT } \\
\text { activity in children with nephrotic syndrome } \\
\text { and correlations of lipid parameters with } \\
\text { PONI and LCAT activity }\end{array}$ & $\begin{array}{l}\text { Two groups: group I (patients) } \\
\text { consisted of } 40 \text { children } \\
\text { with confirmed cases of nephrotic } \\
\text { syndrome in an active phase with } \\
\text { aged 2-14 years of both sexes. } \\
\text { Group } 2 \text { (controls) consisted of } 40 \\
\text { (age- and sex-matched) healthy } \\
\text { controls. }\end{array}$ & $\begin{array}{l}\text { - Case-control study: } \\
\text { - lipid profile and PONI and, lecithin: } \\
\text { cholesterol, acyltransferase activity measured } \\
\text { in both groups' serum samples. }\end{array}$ & $\begin{array}{l}\text { - Albumin significantly lowered in patients. } \\
\text { - Ch, TGs, LDL, significantly increased in patients. } \\
\text { - PONI- and LCAT-activity levels were significantly lower } \\
\text { in patients. } \\
\text { - Significantly decreased PONII and lecithin:cholesterol } \\
\text { acyltransferase activity resulted in increased oxidation of } \\
\text { LDL, thus accelerating atherosclerosis. }\end{array}$ \\
\hline Patnaik et $\mathrm{al}^{35}$ & India & $\begin{array}{l}\text { To define the extent of endothelial } \\
\text { dysfunction by noninvasive evaluation for } \\
\text { impairment of macrovascular and } \\
\text { microvascular endothelial } \\
\text { function in children with NS versus healthy } \\
\text { controls by assessment of brachial artery, } \\
\text { flow-mediated dilation, and cutaneous } \\
\text { postocclusive reactive hyperemia }\end{array}$ & $\begin{array}{l}\text { Total of } 70 \text { steroid-resistant NS } \\
\text { (SRNS) } 70 \text { steroid-sensitive (SSNS) } \\
\text { patients, and } 70 \text { healthy controls } \\
\text { aged I-18 years }\end{array}$ & $\begin{array}{l}\text { - Prospective cohort study with } \\
\text { - two phases: recruitment and baseline } \\
\text { assessment of biomarkers of endothelial } \\
\text { dysfunction (phase I) and prospective follow- } \\
\text { up and cardiovascular outcome assessment } \\
\text { (phase 2). } \\
\text { - After baseline assessment of functional and } \\
\text { structural status of the heart, arteries, } \\
\text { patients were investigated for endothelial } \\
\text { dysfunction. } \\
\text { - Venous blood samples ( } 15 \mathrm{~mL} \text { ) were } \\
\text { collected for routine investigations and } \\
\text { assays of biochemical endothelial markers. } \\
\text { - Patients were followed up at } 12 \text { and } 24 \\
\text { months after recruitment to look for any } \\
\text { change from baseline. }\end{array}$ & $\begin{array}{l}\text { - This study may be able to delineate progression of } \\
\text { endothelial dysfunction in relation to - disease activity } \\
\text { (extent and duration of proteinuria) and structural markers } \\
\text { of subclinical atherosclerosis } \\
\text { - It may also provide correlation of cardiovascular risk } \\
\text { factors with endothelial dysfunction and subclinical } \\
\text { atherosclerosis for pediatric cardiovascular risk } \\
\text { stratification in nephrotic syndrome. }\end{array}$ \\
\hline
\end{tabular}


Table I (Continued).

\begin{tabular}{|c|c|c|c|c|c|}
\hline Study & Country & Aim & Sample & Methods & Findings \\
\hline Biswas et $\mathrm{al}^{16}$ & India & $\begin{array}{l}\text { To investigate changes in fractions of lipid and } \\
\text { lipoprotein levels, as well as apolipoprotein } \\
\text { concentrations so that (if necessary) early } \\
\text { treatment can be started to prevent } \\
\text { complications of atherosclerosis }\end{array}$ & $\begin{array}{l}\text { Two groups of were selected: } \\
\text { group A had } 30 \text { children with } \\
\text { nephrotic syndrome and group } \\
\text { B } 26 \text { age- and sex-matched healthy } \\
\text { controls. }\end{array}$ & $\begin{array}{l}\text { - Cross-sectional study. } \\
\text { - Blood samples were drawn from all subjects } \\
\text { following a fast of } 12 \text { hours. Serum } \\
\text { triglycerides, cholesterol, HDL cholesterol } \\
\text { (direct) and LDL cholesterol (direct) were } \\
\text { estimated. } \\
\text { - Serum apolipoprotein AI and B were also } \\
\text { estimated. }\end{array}$ & $\begin{array}{l}\text { - Group A children had significant hyperlipidemia in the } \\
\text { form of increased serum total cholesterol, triglycerides, } \\
\text { LDL cholesterol, and apolipoprotein B compared to group } \\
\text { B children. } \\
\text { - HDL:LDL cholesterol, HDL cholesterol:triglyceride, } \\
\text { HDL cholesterol were all significantlyincreased in group } \\
\text { A children compared to group B children. } \\
\text { - Apolipoprotein AI:B was significantlydecreased in group } \\
\text { A children compared to group B children. }\end{array}$ \\
\hline $\begin{array}{l}\text { Arumugam } \\
\text { et } \mathrm{al}^{36}\end{array}$ & India & $\begin{array}{l}\text { To evaluate ETI status in children with first- } \\
\text { episode idiopathic } \\
\text { nephrotic syndrome }\end{array}$ & $\begin{array}{l}\text { Fifty children ( } 25 \text { cases and } 25 \\
\text { controls) aged } \mathrm{I}-15 \text { years }\end{array}$ & $\begin{array}{l}\text { - Analytical study with longitudinal follow-up. } \\
\text { ETI was measured } \\
\text { - at onset of disease and after } 12 \text { weeks of } \\
\text { drug-induced remission, and sampling was } \\
\text { done longitudinally. } \\
\text { - Blood samples ( } 3 \mathrm{~mL} \text { ) were collected by } \\
\text { venepuncture. }\end{array}$ & $\begin{array}{l}\text { - Children with nephrotic syndrome had high serum } \\
\text { cholesterol, serum LDL, serum VLDL, serum triglycerides, } \\
\text { and nephrotic range proteinuria, as expected. } \\
\text { - ETI was significantly higher in children with first-episode } \\
\text { of nephrotic syndrome than controls. } \\
\text { - In SSNS at onset, ETI was significantly lower after I2 } \\
\text { weeks of drug-induced remission than controls. } \\
\text { - SRNS children had higher levels of ETI than SSNS ones at } \\
\text { onset, but this was not statistically significant. }\end{array}$ \\
\hline $\begin{array}{l}\text { El Ghannam } \\
\text { et al }{ }^{15}\end{array}$ & Egypt & $\begin{array}{l}\text { To estimate protein } C \text { quantity and quality in } \\
\text { the blood of nephrotic patients for possible } \\
\text { roles that it might play in the pathogenesis of } \\
\text { thromboembolic complications in these } \\
\text { patients and try to find correlations between } \\
\text { protein } C \text { and some hemostatic parameters }\end{array}$ & $\begin{array}{l}\text { Forty children diagnosed with } \\
\text { nephrotic syndrome and } 20 \text { healthy } \\
\text { children as controls }\end{array}$ & $\begin{array}{l}\text { - Morning urine samples were taken for } \\
\text { albumin:creatinine ratio and blood samples for } \\
\text { - complete blood count, serum creatinine, } \\
\text { serum albumin, serum total protein, ACR in } \\
\text { urine, serum cholesterol, serum triglycerides, } \\
\text { coagulation profile (PT-APTT), and } \\
\text { quantitative determination of protein C }\end{array}$ & $\begin{array}{l}\text { - There was a highly significant increase in protein } C \text { in } \\
\text { both activity and concentration in relapse, but in remission } \\
\text { levels decreased toward normal levels. } \\
\text { - Serum albumin and serum total protein were very } \\
\text { significantly increased in relapse and remission compared to } \\
\text { controls. } \\
\text { - PT and PTT were highly significantly decreased in relapse } \\
\text { compared to the control group. } \\
\text { - Increased levels of protein C in nephrotic syndrome } \\
\text { denoted that it had no role in thromboembolic } \\
\text { complications, and increased levels of protein C in } \\
\text { nephrotic syndrome may afford some protection against } \\
\text { thrombotic diathesis by counteracting hypercoagulability. }\end{array}$ \\
\hline $\begin{array}{l}\text { Sugimoto } \\
\text { et } \mathrm{al}^{37}\end{array}$ & Japan & $\begin{array}{l}\text { To examine cholesterol composition, including } \\
\text { sdLDL-C level, in NS, referring to the } \\
\text { "alternative LDL window" to provide better } \\
\text { understanding of the lipid profiles of } \\
\text { childhood-onset NS }\end{array}$ & $\begin{array}{l}\text { A total of } 87 \text { patients were } \\
\text { included, of whom } 39 \text { were } \\
\text { enrolled for the final analysis after } \\
\text { applying the exclusion criteria. }\end{array}$ & $\begin{array}{l}\text { - Retrospective study: } \\
\text { - laboratory data for serum creatinine, } \\
\text { estimated GFR, serum concentrations of total } \\
\text { protein, albumin, total cholesterol, } \\
\text { triglycerides, LDL-C, HDL-C, uric acid, and } \\
\text { creatinine levels were examined. } \\
\text { - Non-HDL-C concentrations of urinary } \\
\text { protein and creatinine were also measured. }\end{array}$ & $\begin{array}{l}\text { - Lipid abnormalities, ie, TC, TGs, LDL-C, and non-HDL-C } \\
\text { levels, were significantly higher than baseline. } \\
\text { - A total of } 32 \text { ( } 82 \% \text { ) exhibited hyper-TGs/non-HDL levels } \\
\text { - There were markedly increased lipid profiles during the } \\
\text { acute phase of nephrotic syndrome. }\end{array}$ \\
\hline
\end{tabular}




\begin{tabular}{|c|c|c|c|c|c|}
\hline Jagadeeswari ${ }^{21}$ & India & $\begin{array}{l}\text { To examine thyroid status in children with } \\
\text { nephrotic syndrome in comparison to children } \\
\text { without nephrotic syndrome }\end{array}$ & Sixty children aged I-8 years & $\begin{array}{l}\text { - Comparative study: } 30 \text { children } \\
\text { - were admitted for reasons other than } \\
\text { nephrotic syndrome and } 30 \text { were suffering } \\
\text { from nephrotic syndrome. } \\
\text { - Serum } \mathrm{FT}_{3}, \mathrm{FT}_{4} \text {, and TSH were measured. }\end{array}$ & $\begin{array}{l}\text { - } \mathrm{FT}_{4} \text { and } \mathrm{FT}_{3} \text { levels in the nephrotic syndrome patients } \\
\text { were significantlylower than the control group. } \\
\text { - TSH levels were high in the nephrotic syndrome group. } \\
\text { - Hypothyroidism was found more in children aged }<6 \\
\text { years than those aged }>6 \text { years, which was statistically } \\
\text { significant. } \\
\text { - Nephrotic syndrome commonly has a state of mind or } \\
\text { subclinical hypothyroidism during proteinuria. }\end{array}$ \\
\hline $\begin{array}{l}\text { Kaczmarek } \\
\text { et al }{ }^{28}\end{array}$ & Poland & $\begin{array}{l}\text { This study investigated oral health parameters } \\
\text { in youngparticipants suffering from nephrotic } \\
\text { syndrome and compared them to healthy } \\
\text { ones. }\end{array}$ & $\begin{array}{l}\text { Male and female participants } \\
(n=110) \text { aged } 4-17 \text { years }\end{array}$ & $\begin{array}{l}\text { - Observational study comparing oral health } \\
\text { in NS patients with healthy outpatients } \\
\text { attending the dental clinic. } \\
\text { - Dental examinations were performed using } \\
\text { artificial light, a plane mirror, and a ball-ended } \\
\text { dental probe. }\end{array}$ & $\begin{array}{l}\text { - The prevalence of enamel hypoplasia in the NS group was } \\
\text { over sevenfold that of the control group. } \\
\text { - roup had double the incidence of severe gingivitis of } \\
\text { controls. } \\
\text { - Significantly worse oral hygiene in the NS group caused } \\
\text { gingival inflammation due to dental plaque accumulation. }\end{array}$ \\
\hline $\begin{array}{l}\text { Alfakeekh } \\
\text { et al's }\end{array}$ & $\begin{array}{c}\text { Saudi } \\
\text { Arabia }\end{array}$ & $\begin{array}{l}\text { To estimate the immunosuppressive burden } \\
\text { and identify clinical risk factors in patients with } \\
\text { primary childhood nephrotic syndrome } \\
\text { (PCNS) }\end{array}$ & $\begin{array}{l}\text { Patients aged } \leq 14 \text { years with } \\
\text { PCNS }(n=11 I \text { ) admitted to the } \\
\text { Department of Paediatrics }\end{array}$ & $\begin{array}{l}\text { - Cross-sectional study of hospitalized } \\
\text { children. } \\
\text { - Infection was classified into major and } \\
\text { minor types. The major types were urinary } \\
\text { tract infection (UTI), pneumonia, and } \\
\text { peritonitis. }\end{array}$ & $\begin{array}{l}\text { - In sum, } 84(76.4 \%) \text { had both minor and major types of } \\
\text { infection. } \\
\text { - About half the infections encountered by PCNS patients } \\
\text { were upper respiratory tract infection (URTI, followed by } \\
\text { UTI and pneumonia. } \\
\text { - URTI was the predominant infection noted in our study. } \\
\text { Among the major infections, UTI was the main type ( } n=21 \text {, } \\
25 \%) \text {, followed by pneumonia }(n=17,20 \% \text { ) then cellulitis } \\
(n=6,6 \%) \text {. }\end{array}$ \\
\hline Yaseen et a $\mathrm{al}^{38}$ & Pakistan & $\begin{array}{l}\text { To determine the clinical profile of children } \\
\text { with INS who developed AKI and its } \\
\text { short-term outcomes }\end{array}$ & $\begin{array}{l}\text { A total of } 119 \text { children aged } 2-18 \\
\text { years with INS }\end{array}$ & $\begin{array}{l}\text { - Prospective observational study. } \\
\text { - The primary end point was normalization of } \\
\text { renal functions. Patients were followed for } 3 \\
\text { months after an episode of AKI to observe } \\
\text { outcomes (CKD/death/ recovered). }\end{array}$ & $\begin{array}{l}\text { - Most respondents had steroid-resistant nephrotic } \\
\text { syndrome and focal segmental glomerulosclerosis on } \\
\text { histopathology. } \\
\text { - Infections were the major predisposing factor for AKI } \\
\text { cases, followed by drug toxicity. } \\
\text { - A total of } 54.6 \% \text { of children recovered from AKI, while } \\
45.4 \% \text { did not. } \\
\text { - CKD developed in } 41.2 \% \text { of non-recovered cases. }\end{array}$ \\
\hline
\end{tabular}




\section{Study Quality}

We used the Joanna Briggs Institute's critical appraisal tools for assuring the quality of the journal articles that were chosen for systematic review. These consist of several checklists based on research methods, and were used to assist in assessing the trustworthiness, relevance, and results of published papers.

\section{Results}

\section{Publication Characteristics and Quality}

A total of 11,717 articles were retrieved from the nine databases after removal of duplicates and one study in Arabic. We exclude 11,612: 8,942 did not report complications in childhood NS, 1,021 involved adults as subjects, 759 did not discuss NS only, 687 were case reports, and 203 were reviews. This resulted in 93 articles for full-text review. Finally, eleven articles were analyzed. A PRISMA flowchart ${ }^{13}$ of the search is shown in Figure 1.

\section{Disease-Associated Systemic Complications of Childhood NS Cardiovascular Complications}

Cardiovascular complications of NS include increased risk of atherosclerosis and thromboembolism, due to dysregulated lipid metabolism and dyslipidemia. ${ }^{14}$ Thromboembolic causes are among the most serious complications in patients with NS. ${ }^{15}$ Also, complications of atherosclerosis are a major cause of death and increase the need for dialysis and risk of renal transplantation. ${ }^{16}$ One study that used blood samples of pediatric patients with NS found lipid-profile abnormalities. Total cholesterol, low-density lipoprotein (LDL) cholesterol, triglyceride, and ET1 levels were significantly higher in the NS group than the control group, while high-density lipoprotein (HDL) cholesterol, albumin, PON1, and lecithin:cholesterol acyltransferase activity levels were significantly lower. The change of brachial artery diameter was significantly lower in the NS group than the control group. The significantly decreased PON1 and lecithin:cholesterol acyltransferase activity resulted in increased oxidation of LDL, causing accelerated atherosclerosis. This study's results may represent the pathogenesis in the progression of endothelial dysfunction related to disease activity (extent and duration of proteinuria) and structural markers of subclinical atherosclerosis. They may also delineate the correlation of cardiovascular risk factors with endothelial dysfunction and subclinical atherosclerosis in childhood NS. The long-term survival of patients with NS is increasingly dependent on controlling the risk factors of atherosclerosis. Therefore, there is a need to evaluate lipid and lipoprotein levels early so that appropriate treatment can start quickly. ${ }^{16}$

\section{Infections}

Childhood NS carries a high risk of complications, including infection. The pathogenesis of the increased infection frequency is linked to defects in cell-mediated immunity, urinary loss of immunoglobulins, properdin factor band B, and complement factors. ${ }^{17}$ Alfakeekh et al showed that $76.4 \%$ of patients with childhood NS had both minor and major types of infection. Over half the infections encountered by patients with childhood NS were upper respiratory tract infection, followed by urinary tract infection, pneumonia, and cellulitis. ${ }^{18}$

\section{Thyroid-Hormone Complications}

Metabolic abnormalities, such as deranged coagulation, immunodeficiency from immunoglobulin and complement loss, and anemia from erythropoietin and transferrin deficiency, are linked with low molecular-weight proteins, including some binding proteins, that are excreted in patients with NS. Thyroid hormones and binding globulins are also excreted in urine in excess, and NS patients may show hypothyroidism. ${ }^{19}$ Thyroid hormones have prominent roles in growth and development, proper functioning of the central nervous system, cardiovascular function, and homeostasis. Subclinical hypothyroidism has been associated with hypertension, dyslipidemia, and cardiovascular morbidities through endothelial dysfunction. ${ }^{20}$ Jagadeeswari showed that hypothyroidism was more common in children with $\mathrm{NS} \mathrm{FT}_{4}$ and $\mathrm{FT}_{3}$ levels in patients with NS were significantly lower than the control group, while TSH level was high. Hypothyroidism was found significantly more in children aged $<6$ years than those aged $>6$ years. NS commonly presents with subclinical hypothyroidism during proteinuria. ${ }^{21}$ 


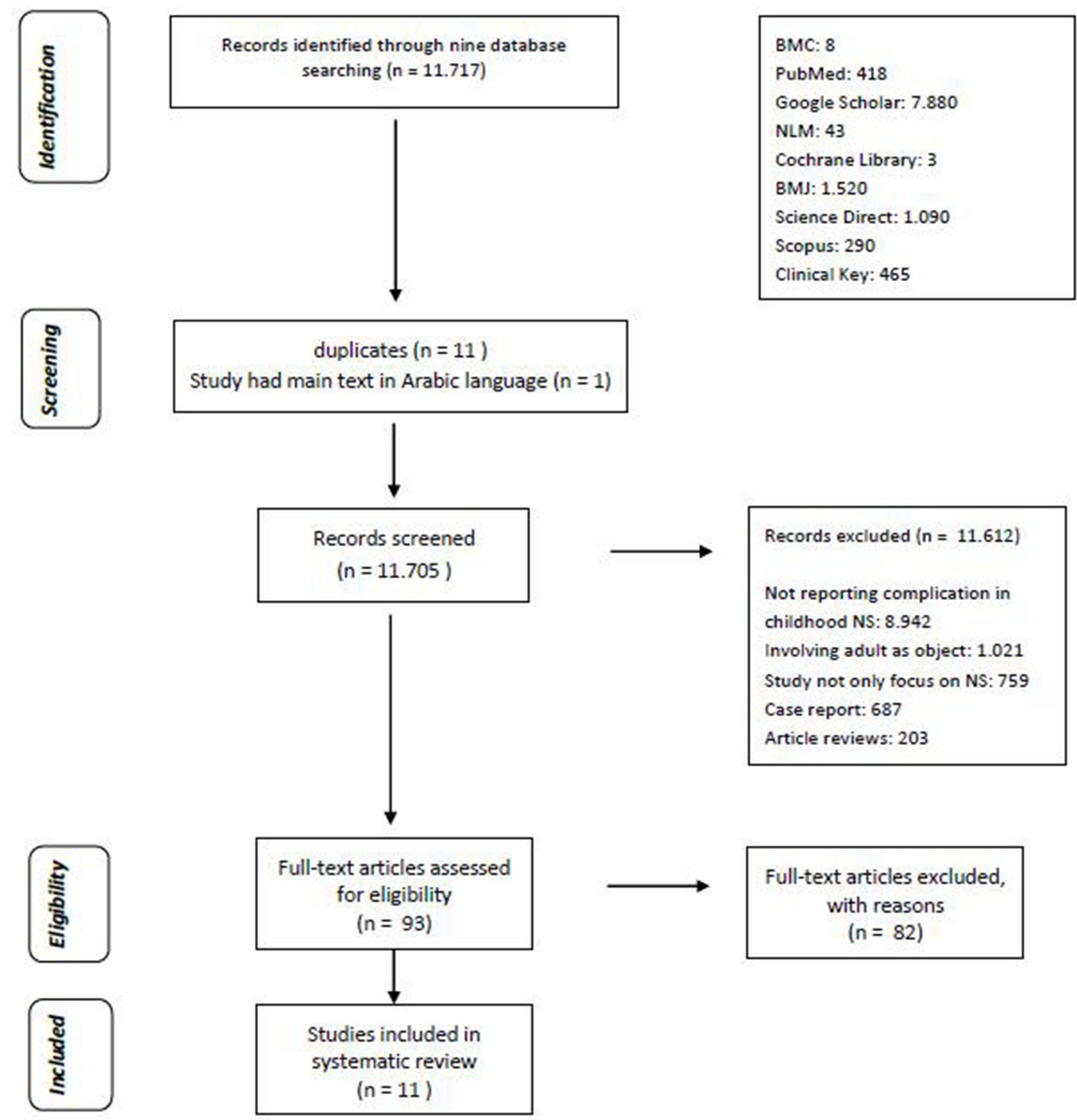

Figure I Flowchart of study search and selection. Adapted from Page MJ, McKenzie JE, Bossuyt PM, Boutron I, Hoffmann TC, Mulrow CD. PRISMA 2020 flow diagram. Bmj. 2020;372(n7I). http://www.prisma-statement.org/PRISMAStatement/FlowDiagram. ${ }^{13}$

\section{Kidney Complications}

One of the important and alarming complications of idiopathic NS is acute kidney injury (AKI). ${ }^{22}$ The etiology of AKI with NS includes acute renal tubular necrosis, toxicity of drugs, such as calcineurin inhibitors, angiotensin-converting enzyme inhibitors, and angiotensin-receptor blockers, sepsis, renal vein thrombosis, peritonitis, and interstitial nephritis. ${ }^{23}$ Yaseen et al showed that most subjects had focal segmental glomerulosclerosis on histopathology. Infections were a major predisposing factor for AKI. A total of 54.6\% recovered from AKI, $45.4 \%$ did not, and chronic kidney disease developed in $41.2 \%$ of the non-recovered cases. ${ }^{24}$ 


\section{Oral Health Complications}

Disturbance of calcium homeostasis in NS is linked with hypocalcemia, reduced vitamin D metabolites in serum, weakened intestinal absorption of calcium, and raised levels of parathyroid hormone, which lead to abnormal bone histology. ${ }^{25}$ Developmental defects of enamel result from disruption in calcium and phosphorus absorption and poor metabolism of vitamin D occurring during the formation of enamel in developing teeth. ${ }^{26}$ Irregular tooth cleaning and dental checkups result in the neglect of oral hygiene, and are major concerns in patients with NS. The removal of dental biofilm can predispose patients to inflammation of gingival tissue and caries, and gingival hyperplasia is associated with drug use and increased risk of destructive periodontal diseases. ${ }^{27}$ Kaczmarek et al found that the prevalence of enamel hypoplasia in NS patients was over sevenfold that of controls, and patients with NS had double the incidence of severe gingivitis of controls. The significantly worse oral hygiene in the NS group caused gingival inflammation due to dental plaque accumulation. ${ }^{28}$

\section{Discussion}

NS is one of the most common glomerular diseases in the spectrum of childhood renal diseases. These children have lesions of focal segmental glomerulosclerosis and suffer from severe and prolonged proteinuria that has been linked to a higher risk of systemic complications. The main pathomechanism of disease-associated complications in children with NS originates from the large loss of plasma protein via urine. This systematic review shows that the disease-associated systemic complications in childhood NS include cardiovascular complications, infections, thyroid complications, kidney complications, and poor oral health condition, ie, caries and enamel hypoplasia.

Arterial and venous thromboembolic complications are relatively common and bring serious consequences for pediatric patients with NS. Multiple abnormalities in the coagulation pathways are observed in NS that are linked to thromboembolism. This was supported by a review conducted by Zaffanello and Franchini in 2007 that indicated that the risk of thromboembolism in childhood NS should not be underestimated and had become the most-serious lifethreatening complication. The most commonly involved vessels in vascular thrombosis are the deep veins of the legs, inferior vena cava, renal veins, superior vena cava, mesenteric artery, hepatic veins, and middle cerebral arteries. Iatrogenic thrombotic risk factors (diuretics, dehydration, and infections) should be avoided. The therapeutic approach to childhood thrombosis is anticoagulants (low molecular-weight heparin and/or fibrinolytic agents, such as streptokinase, urokinase, or tissue plasminogen activators). ${ }^{29}$

Smoyer et al found that $7.4 \%$ of thromboses occurred during NS remission, of which renal vein thrombosis and pulmonary embolism were the most common - 33.3\% and 25.9\%, respectively. Most of the NS children with thromboembolisms (70.4\%) resolved completely. ${ }^{30,31}$ Patients with childhood NS show lipid-profile abnormalities due to changes in the metabolism of lipoprotein, which then changes lipids' nature, both quantitatively and qualitatively. This was supported by a study conducted by Al-Bahrani in 2017 that showed that hyperlipidemia was one of the most common features of NS. Any abnormalities in lipid levels can lead to atherosclerotic, cardiovascular, and thromboembolic complications and lipid accumulation in glomeruli and proximal tubular epithelial cells. It is essential to maintain lipid levels in the body for good health. ${ }^{32}$

Various medical conditions can affect oral health. Patients with childhood NS have such oral complications as removal of dental biofilm, gingival inflammation, defects in enamel, and enamel hypoplasia. This is supported by a review conducted by Gupta et al in 2014 indicating that in pediatric patients, renal disease, including NS, can affect oral condition, both hard and soft tissue. Oral manifestations in soft tissue include stomatitis (mucositis), can cause inflammation of the tongue and oral mucosa. Altered taste sensation, dysgeusia, gingival inflammation, and candidiasis infection can develop due to underlying renal disease. In hard tissue, enamel hypoplasia in the form of white or brown discoloration of primary teeth occurs and is correlated with the metabolic disturbance of renal disorders, including NS. ${ }^{27}$

This was a novel systematic review of disease-associated complications in childhood NS that drew on data from seven countries. The number of studies included was limited due to the low number of studies available on diseaseassociated complications in childhood NS. Further studies should explore psychological and developmental complications in children with NS. 


\section{Conclusion}

NS is one of the most common childhood kidney diseases. Patients with childhood NS suffer a loss of proteins that negatively affects various biological functions during active disease and can result in disease-associated complications. These children also have lesions of focal segmental glomerulosclerosis and suffer from severe and prolonged proteinuria, which has been linked to a higher risk of systemic complications. Complications in pediatric patients with NS include cardiovascular complications linked to atherosclerosis and thromboembolism, infections (both minor and major), thyroidhormone complications, especially hypothyroidism, kidney complications involving AKI, oral health complications due to defects in enamel, and periodontal disease. These complications need the attention of health-care providers to prevent any worsening of patients' condition. Further research should also explore complications related to psychological and developmental problems that might decrease the quality of life in children with NS.

\section{Disclosure}

The authors report no conflicts of interest in this work.

\section{References}

1. Shatat IF, Becton LJ, Woroniecki RP. Hypertension in childhood nephrotic syndrome. Front Pediatr. 2019;7(July):1-9. doi:10.3389/ fped.2019.00287

2. Kaczmarek U, Wrzyszcz-kowalczyk A, Jankowska K, Pro K. Oral health conditions in children with idiopathic nephrotic syndrome: a crosssectional study. BMC Oral Health. 2020;1:1-9.

3. Wang C, Yan J, Palmer R, Bost J, Wolf MF, Greenbaum LA. Childhood nephrotic syndrome management and outcome: a single center retrospective analysis. Int J Med. 2017;2017:345.

4. Wang C. Nephrotic Syndrome. Pediatr Clin NA. 2021;66(1):73-85. doi:10.1016/j.pcl.2018.08.006

5. Nakanishi K, Iijima K, Ishikura K, et al. Two-year outcome of the ISKDC Regimen and frequent-relapsing risk in children with idiopathic nephrotic syndrome. Clin J Am Soc Nephrol. 2013;8(5):756-762. doi:10.2215/CJN.09010912

6. Barnett L. International study of kidney disease in children. Nihon Jinzo Gakkai Shi. 1979;10(53):1141-1144.

7. Edelmann CM, Spitzer A, Kuijten RH, et al. The primary nephrotic syndrome in children. Identification of patients with minimal change nephrotic syndrome from initial response to prednisone. J Med. 1981;98(4):561-564.

8. Micheal M, Abdel-hamid MS. Genetic mutation in Egyptian children with steroid-resistant nephrotic syndrome. J Formos Med Assoc. 2018;117 (1):48-53. doi:10.1016/j.jfma.2017.02.012

9. Garibotto G, Giannoni M, Salvatore F. Complications of the nephrotic syndrome. G Ital Nefrol. 2003;20(1):49-60.

10. Bakkum L, Willemen AM, Zoetebier L, Bouts AH. A longitudinal study on the effects of psychological stress on proteinuria in childhood steroid-sensitive nephrotic syndrome. J Psychosom Res. 2019;121:(January):8-13. doi:10.1016/j.jpsychores.2019.01.011

11. Manti P, Giannakopoulos G, Giouroukou E, et al. Psychosocial and cognitive function in children with nephrotic syndrome: association with disease and treatment variables. Biopsychosoc Med. 2013;7(1):1-7. doi:10.1186/1751-0759-7-10

12. Aydin M, Franke I, Kurylowicz L, Ganschow R, Lentze M, Born M. The long-term outcome of childhood nephrotic syndrome in Germany: a cross-sectional study. Clin Exp Nephrol. 2019;1:968. doi:10.1007/s10157-019-01696-8

13. Page MJ, McKenzie JE, Bossuyt PM, Boutron I, Hoffmann TC, Mulrow CD. PRISMA 2020 flow diagram. Bmj. 2020;372(n71). http://www. prisma-statement.org/PRISMAStatement/FlowDiagram

14. Ali RJ, Baban RS, Ali SH. Evaluation of Lipid metabolizing enzymes: paraxonase1(PON1) and Lecithin Cholesterol acyltransferase (LCAT) activities in children with nephrotic syndrome. Baghdad J Biochem Appl Biol Sci. 2021;2(1):47-58. doi:10.47419/bjbabs.v2i01.38

15. El Ghannam MZ, Ali AAEM, El Samanoudy MI, Kamel AR. Assessment of The Level of Protein C in Children with Nephrotic Syndrome. Egypt J Hosp Med. 2019;76(3):3828-3834. doi:10.21608/ejhm.2019.41345

16. Biswas A, Basu R, Basu K. Nephrotic Syndrome Induced Dyslipidemia in Children and Need for Early Assessment. J Med Dent Sci Res. 2017;3 (12):35-38.

17. Wei CC, Yu IW, Lin HW, Tsai AC. Occurrence of infection among children with nephrotic syndrome during hospitalizations. Nephrology. 2012;17 (8):681-688. doi:10.1111/j.1440-1797.2012.01650.x

18. Alfakeekh K, Azar M, Al SB, et al. Immunosuppressive burden and risk factors of infection in primary childhood nephrotic syndrome. $J$ Infect Public Health. 2019;12(1):90-94. doi:10.1016/j.jiph.2018.09.006

19. Gilles R, den Heijer M, Ross AH, Sweep FCGJ, Hermus ARMM, Wetzels JFM. Thyroid function in patients with proteinuria. Neth J Med. 2008;66 (11):483-485.

20. Singh S, Mishra OP, Mandal PP, et al. Thyroid function in patients with idiopathic nephrotic syndrome. Int Urol Nephrol. 2021;53(9):1859-1864. doi:10.1007/s11255-020-02778-3

21. Jagadeeswari S. A study on thyroid function test in children with nephritic syndrome admitted to a tertiary care hospital. Drug Invent Today. 2019;11(11):2699-2701.

22. Rheault M, Wei C, Hains D, Wang W, Kerlin B. Increasing frequency of acute kidney injury among children hospitalized with nephrotic syndrome. Pediatr Nephrol. 2014;29:139-147. doi:10.1007/s00467-013-2607-4

23. Smith JD, Hayslett JP. Reversible renal failure in the nephrotic syndrome. Am J Kidney Dis. 1992;19(3):201-213. doi:10.1016/S0272-6386(13) 80001-7

24. Yaseen A, Tresa V, Lanewala AA, Hashmi S, Ali I, Khatri S. Acute kidney injury in idiopathic nephrotic syndrome of childhood is a major risk factor for the development of chronic kidney disease. Ren Fail. 2017;1:323-327. doi:10.1080/0886022X.2016.1277743 
25. Esmaeeili M, Azarfar A, Hoseinalizadeh S. Calcium and vitamin D metabolism in pediatric nephrotic syndrome; an update on the existing literature. Int J Pediatr. 2015;3(2):103-109. doi:10.22038/ijp.2015.3932

26. Koch MJ, Bührer R, Pioch T, Schärer K. Enamel hypoplasia of primary teeth in chronic renal failure. Pediatr Nephrol. 1999;13(1):68-72. doi:10.1007/s004670050566

27. Gupta M, Gupta M. Oral conditions in renal disorders and treatment considerations - A review for pediatric dentist. Saudi Dent J. 2015;27 (3):113-119. doi:10.1016/j.sdentj.2014.11.014

28. Kaczmarek U, Wrzyszcz-Kowalczyk A, Jankowska K, et al. Oral health conditions in children with idiopathic nephrotic syndrome: a cross-sectional study. BMC Oral Health. 2020;20(1):1-9. doi:10.1186/s12903-020-01197-1

29. Zaffanello M, Franchini M. Thromboembolism in childhood nephrotic syndrome: a rare but serious complication. Hematology. 2007;12(1):69-73. doi:10.1080/10245330600940048

30. Kerlin BA, Ayoob R, Smoyer WE. Epidemiology and pathophysiology of nephrotic syndrome-associated thromboembolic disease. Clin J Am Soc Nephrol. 2012;7(3):513-520. doi:10.2215/CJN.10131011

31. Lv Y-L, Guan N, Ding J, et al. Spectrum of thrombotic complications and their outcomes in Chinese children with primary nephrotic syndrome. Ital $J$ Pediatr. 2020;46(1):182. doi:10.1186/s13052-020-00942-0

32. AL-Bahrani MHA. The evolution of lipid metabolism in Iraqi children with nephrotic syndrome. Biomed Pharmacol J. 2017;10(4):1917-1924. doi:10.13005/bpj/1311

33. Youssef DM, Gomma MA, El-Akhras A, et al. Brachial Artery Flow-mediated Dilatation and Carotid Intima- Media Thickness in Children With Idiopathic Nephrotic Syndrome. Kidney Dis. 2018;9(3):266-276.

34. Ali R, Baban R, Ali S. Evaluation of lipid metabolizing enzymes: Paraxonase1 (PON1) and lecithin cholesterol acyltransferase (LCAT) activities in children with nephrotic syndrome. Baghdad J Biochem Appl Biol Sci. 2021;2(01):48-59. doi:10.47419/bjbabs.v2i01.38

35. Patnaik SK, Kumar P, Bamal M, et al. Cardiovascular outcomes of Nephrotic syndrome in childhood (CVONS) study: A protocol for prospective cohort study. BMC Nephrol. 2018;19(1):1-10. doi:10.1186/s12882-018-0878-5

36. Arumugam V, Saha A, Kaur M, et al. Endothelin 1 and endothelial dysfunction in children with idiopathic nephrotic syndrome. Artery Res. 2017;18 (December):36-40. doi:10.1016/j.artres.2017.02.006

37. Sugimoto K, Kinki KM, Igakubu D, et al. Markedly Increased Small Dense Low-Density Lipoprotein During Acute Phase in Childhood and Adolescent Nephrotic Syndrome. Res Sq. Published online 2020:1-10. doi:10.21203/rs.3.rs-55523/v1

38. Yaseen A, Tresa V, Lanewala AA, et al. Acute kidney injury in idiopathic nephrotic syndrome of childhood is a major risk factor for the development of chronic kidney disease. Ren Fail. 2016;39(1):323-327. doi:10.1080/0886022X.2016.1277743

International Journal of Nephrology and Renovascular Disease

Dovepress

\section{Publish your work in this journal}

The International Journal of Nephrology and Renovascular Disease is an international, peer-reviewed open-access journal focusing on the pathophysiology of the kidney and vascular supply. Epidemiology, screening, diagnosis, and treatment interventions are covered as well as basic science, biochemical and immunological studies. The manuscript management system is completely online and includes a very quick and fair peer-review system, which is all easy to use. Visit http://www.dovepress.com/testimonials.php to read real quotes from published authors.

Submit your manuscript here: https://www.dovepress.com/international-journal-of-nephrology-and-renovascular-disease-journal 